\title{
Editorial:
}

\section{Trends in Marketing Capabilities}

\author{
Tendencias en capacidades de marketing
}

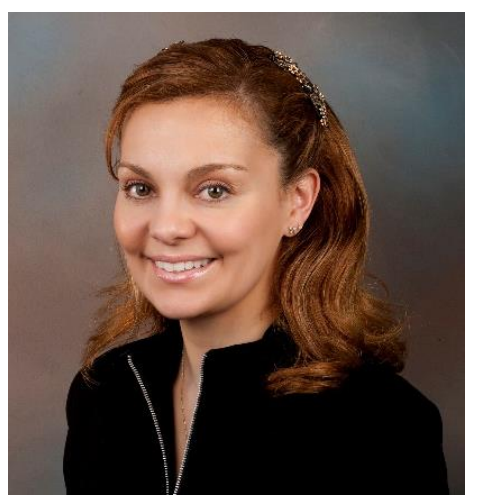

Silvia L. Martin

Associate Professor of Marketing

California State University United States of America

E-mail: smart236@calstatela.edu

https://doi.org/10.22430/24223182.1865

The business environment of small and medium enterprises (SMEs) has dramatically changed in recent years, demanding firms to adapt and thrive in competitive conditions. For instance, rapid changes or crises could suddenly appear, requiring these organizations to develop and sustain competitive advantages by deploying marketing capabilities in order to fight their competitors in local and international markets (Martin \& Javalgi, 2019). Furthermore, although SMEs might encounter resource limitations, evidence shows that they prioritize and invest significant resources in building, maintaining, and leveraging marketing capabilities (Tan \& Sousa, 2015), which can improve business performance (Martin et al., 2017; Murray et al., 2011). For these reasons, research into marketing capabilities should be expanded to answer questions such as: What are marketing capabilities? How can a business implement them? What are some trends that require special attention?

To address these questions and forecast some key marketing capabilities for future research, this editorial is organized as follows: First, I define and outline the characteristics of marketing capabilities. Then, I expand the understanding of three key capabilities: new product, new service, and ecommerce. Finally, I draw the most important conclusions.

Marketing Capabilities are built around the Resource-Based View (RBV). The RBV posits that a firm's competitive advantage is based on resource management and capabilities control, which are rare, 
valuable, difficult to imitate, and not substitutable. Additionally, resources and capabilities can take the form of internal processes, assets, business skills, and knowledge and information management, among others (Barney, 1991). Considering this framework, marketing capabilities can be defined as comprehensive processes designed to apply a firm's necessary resources to its market-related needs, thus enabling the organization to add value and fulfill competitive demands (Day, 2011). The literature shows that some marketing capabilities are closely related to a competitive strategy that combines low cost and marketing differentiation (Hughes et al., 2010). Commonly, firms pursue cost leadership to offer customers lower prices than their competitors', while marketing differentiation allows SMEs to create new and distinctive products (Banker et al., 2014; Li \& Deng, 2017). Therefore, firms that have marketing capabilities related to new product development, service, and distribution can effectively create and launch new products, services, and supply chains; they can also generate competitive advantages based on differentiation and cost leadership to meet the needs of international consumers (Martin et al., 2020).

\section{Service Capability}

Service capability is the degree to which a firm can apply a distinctive attribute that differentiates it from the competition, enhance customer relationships, and achieve service advantage (Yang et al., 2009). Service has a strong influence on customer purchase behavior because consumers tend to choose firms that provide high-quality services. Evidence of this is found in the literature on international production, where service capabilities such as customer response, service reliability, and value-added services have been associated with better business performance (Lu, 2003). For instance, Vorhies and Morgan (2005) found, through a study of 12 end-consumer and service industries, that marketing capabilities improve customer satisfaction, market effectiveness, and profitability. Similarly, Innis and La Londe (1994) confirmed a positive impact of service capability on customer satisfaction, customer loyalty, and market share.

\section{New Product Capability}

New product capabilities cause SMEs to increase their stock for existing and new customers, as well as their profits (Slotegraaf \& Pauwels, 2008). Consequently, firms require organizational structural factors to identify customer needs, consumer engagement, and market sensing, which is achieved through product exploration and exploitation (Mu, 2014). To broaden this capability, SMEs should define a customer-based structure to articulate and meet market needs using information. Although developing new products can pose challenges for businesses (mostly related to higher costs, risks, and management problems), it can also improve their competitive advantage (Sheng et al., 2011). Therefore, businesses should overcome these obstacles and take advantage of opportunities by developing new products; otherwise, they might encounter difficulties to reach sustainability in the long-term. Although product innovation and its benefits have been increasingly investigated, their effect on business performance is still unclear (De Luca \& Atuahene-Gima, 2007).

\section{E-commerce}

Rapid changes in the business world and the incorporation of new technologies have pushed firms to leave their "regular" operation environment and adopt and develop e-commerce strategies in order to satisfy the needs of current customers and reach new ones. The e-commerce capability gives firms 
new opportunities to reach global market; as a result, the adoption of electronic commerce has become essential for SMEs, especially in the IT sector, because it expands their customer base, improves customer service, and reduces operating costs (Karavdic \& Gregory, 2005). Such marketing capacity has also demonstrated its potential to generate a differentiation attribute among competitors (Murray et al., 2011). This was proven by Swilley et al. (2012), who found a connection between mobile business development and higher competitive advantage. Likewise, Gregory et al. (2019) found that electronic commerce had a positive effect on distribution and communication efficiency.

\section{Conclusion}

The three marketing capabilities discussed above have been demonstrated to be useful in order to gain long-term competitive advantage and develop differentiating factors against direct competition. Service is a key factor that influences purchase behavior, promotes customer loyalty, and improves trust. New product development promotes growth, increases profit, and creates new opportunities to fulfill new market needs. E-commerce can be implemented to reach new local or international markets, create new market segments, enhance customer service, and improve communication. Thus, future research should further investigate these capabilities. Additionally, as firms will continue to invest significant resources in the development of their organizational capabilities, comprehensive studies should deepen our understanding of such capabilities and identify new ones. As a result, researchers will be able to propose new managerial applications and determine new possible outcomes.

\section{REFERENCES}

Banker, R. D.; Mashruwala, R.; Tripathy, A. (2014). Does a differentiation strategy lead to more sustainable financial performance than a cost leadership strategy? Management Decision, v. 52, n. 5, 872-896. https://doi.org/10.1108/MD-05-2013-0282

Barney, J. B. (1991). Firm resources and sustained competitive advantage. Journal of Management, v. 17, n. $1,99-120$.

Day, G. S. (2011). Closing the Marketing Capabilities Gap. Journal of Marketing, v. 75, n. 4, 183-195. https://doi.org/10.1509/jmkg.75.4.183

De Luca, L. M.; Atuahene-Gima, K. (2007). Market knowledge dimensions and cross-functional collaboration: Examining the different routes to product innovation performance. Journal of Marketing, v. 71, n. 1, 95-112. https://doi.org/10.1509/jmkg.71.1.095

Gregory, G. D.; Ngo, L. V.; Karavdic, M. (2019). Developing e-commerce marketing capabilities and efficiencies for enhanced performance in business-to-business export ventures. Industrial Marketing Management, v. 78, 146-157. https://doi.org/10.1016/j.indmarman.2017.03.002 
Hughes, M.; Martin, S. L.; Morgan, R. E.; Robson, M. J. (2010). Realizing Product-Market Advantage in High-Technology International New Ventures: The Mediating Role of Ambidextrous Innovation. Journal of International Marketing, v. 18, n. 4, 1-21. URL

Innis, D. E.; La Londe, B. J. (1994). Modelling the Effects of Customer Service Performance on Purchase Intentions in the Channel. Journal of Marketing Theory and Practice, v. 2, n. 2, 45-60. https://doi.org/10.1080/10696679.1994.11501650

Karavdic, M.; Gregory, G. (2005). Integrating e-commerce into existing export marketing theories: A contingency model. Marketing Theory, v. 5, n. 1, 75-104. https://doi.org/10.1177/1470593105049602

Li, Q.; Deng, P. (2017). From international new ventures to MNCs: Crossing the chasm effect on internationalization paths. Journal of Business Research, v. 70, 92-100. https://doi.org/10.1016/j.jbusres.2016.07.002

Lu, C. S. (2003). The impact of carrier service attributes on shipper-carrier partnering relationships: a shipper's perspective. Transportation Research Part E: Logistics and Transportation Review, v. 39, n. 5, 399-415. https://doi.org/10.1016/S1366-5545(03)00015-2

Martin, S. L.; Javalgi, R. G. (2019). Explaining performance determinants: A knowledge based view of international new ventures. Journal of Business Research, v. 101, 615-626. https://doi.org/10.1016/i.jbusres.2019.02.041

Martin, S. L.; Javalgi, R. G.; Cavusgil, E. (2017). Marketing capabilities, positional advantage, and performance of born global firms: Contingent effect of ambidextrous innovation. International Business Review, v. 26, n. 3, 527-543. https://doi.org/10.1016/j.ibusrev.2016.11.006

Martin, S. L.; Javalgi, R. G.; Ciravegna, L. (2020). Marketing capabilities and international new venture performance: The mediation role of marketing communication and the moderation effect of technological turbulence. Journal of Business Research, v. 107, 25-37. https://doi.org/10.1016/j.jbusres.2019.09.044

Mu, J. (2014). Networking Capability, Network Structure, and New Product Development Performance. IEEE Transactions of Engineering Management, v. 61, n. 4, 599-609. https://doi.org/10.1109/TEM.2014.2359160

Murray, J.; Gao, G.; Kotabe, M. (2011). Market orientation and performance of export ventures: the process through marketing capabilities and competitive advantages. Journal of the Academy of Marketing Science, v. 39, n. 2, 252-269. https://doi.org/10.1007/s11747-010-0195-4

Sheng, S.; Zhou, K. Z.; Li, J. J. (2011). The effects of business and political ties on firm performance: Evidence from China. Journal of Marketing, v. 75, n. 1, 1-15. https://doi.org/10.1509/jm.75.1.1 
Slotegraaf, R. J.; Pauwels, K. (2008). The impact of brand equity and innovation on the long-term effectiveness of promotions. Journal of Marketing Research, v. 45, n. 3, 293-306.

https://doi.org/10.1509/jmkr.45.3.293

Swilley, E.; Hofacker, C. F.; Lamont, B. T. (2012). The evolution from e-commerce to m-commerce: pressures, firm capabilities and competitive advantage in strategic decision making. International Journal of E-Business Research, v. 8, n. 1, 1-16. https://doi.org/10.4018/jebr.2012010101

Tan, Q.; Sousa, C. M. P. (2015). Leveraging Marketing Capabilities into Competitive Advantage and Export Performance. International Marketing Review, v. 32, n. 1, 78-102. https://doi.org/10.1108/IMR-12-2013-0279

Vorhies, D. W.; Morgan, N. A. (2005). Benchmarking marketing capabilities for sustained competitive advantage. Journal of Marketing, v. 69, n. 1, 80-94. https://doi.org/10.1509/jmkg.69.1.80.55505

Yang, C. C.; Marlow, P. B.; Lu, C. S. (2009). Assessing resources, logistics service capabilities, innovation capabilities and the performance of container shipping services in Taiwan. International Journal of Production Economics, v. 122, n. 1, 4-20.

https://doi.org/10.1016/i.ijpe.2009.03.016 